\title{
ARTICLES
}

\section{GENERAL APPROACHES TO DOMINANT MARKET POSITION, PROHIBITION OF ABUSE OF MARKET POWER, AND MARKET STRUCTURE CONTROL WITHIN THE BRICS COUNTRIES}

\author{
KSENIA BELIKOVA, \\ Peoples' Friendship University of Russia \\ (Moscow, Russia)
}

DOI:10.21684/2412-2343-2016-3-1-7-33

The article presents research on the general approaches taken by BRICS countries through their legislation and legal orders to counteract anticompetitive market strategies such as abuse of dominant market power and market structure control, as a means of both global and regional governance in the legal orders of China, India, Russia, and South Africa. The author pays particular attention to current legislation of the BRICS countries in the field of competition protection with regard to provisions related to (1) the criteria for establishment of a dominant market position and (2) market structure control and restriction of anticompetitive mergers \& acquisitions, and 'concentration' of enterprises' market power control fixed by Asian (China and India), Euro-Asian (Russia), and African (South Africa) legal orders and prohibition of abuse of market power. The article argues that our society is interested in the engagement of the population in trade and industrial activity. This is the general rule. Nowadays, however, this rule allows exceptions: restrictions on freedom of trade can be justified by exceptional circumstances in certain cases and under certain circumstances (e.g. an exemption necessary in the interest of security of the state or public interest). The analysis of substantial contents of the laws on competition and monopolies of the abovementioned BRICS countries and relevant case law shows the existence of a number of conventional, generally acknowledged (unified) provisions and norms. At the same time, there are specific features that make them different. These generally acknowledged provisions and peculiarities are a focus of the article.

Key words: BRICS; protection of competition; restrictive business practices; market power; dominant market position; abuse of market power; prohibition of abuse of market power; market structure control; mergers \& acquisitions. 
Recommended citation: Ksenia Belikova, General Approaches to Dominant Market Position, Prohibition of Abuse of Market Power, and Market Structure Control within the BRICS Countries, 3(1) BRICS Law Journal 7-33 (2016).

\section{Abbreviations}

AML - Anti-Monopoly Law of the People's Republic of China of 2007

BRICS - Grouping of Countries Comprising Brazil, Russia, India, China, and South Africa

M\&As - Mergers \& Acquisitions

MNCs - Multi-National Corporations

OECD - Organization for Economic Cooperation and Development

Table of Contents

\section{Introduction}

2. Discussion

2.1. General Characteristics of Sources of Competition Law Within the Legal Orders of China, India, Russia, and South Africa

2.2. Criteria for Establishment of a Dominant Market Position Fixed by Asian (China and India), Euro-Asian (Russia), and African (South Africa) Legal Orders and Prohibition of Abuse of Market Power

2.3. Anticompetitive M\&As and Market Structure Control Realized by the Responsible Governmental Bodies. General Provision on Restriction (Control) of 'Concentration' of Enterprises' Market Power

2.4. BRICS Domestic Competition Authorities Cross-Border Cooperation and Interaction

\section{Conclusions}

\section{Introduction}

Clubbing together is in the mainstream nowadays. Thus four major emerging national economies - Brazil, Russia, India, and China - clubbed together in 2006 and created BRIC. With South Africa joining in April 2011, the term BRICS has become a widely used acronym for the shifting of global economic power from developed economies to major developing countries.

Given their expanding economic size and increasingly active diplomacy, BRICS countries are gradually gaining greater influence over the international decision-

As for Brazil, see my research: Belikova K. La protección jurídica de la competencia en MERCOSUR, 26 BLC 59-73 (2010), at <http://ec.europa.eu/competition/publications/blc/boletin_27.pdf> (accessed Nov. 17, 2010). 
making process. It was even forecasted by Goldman Sachs that BRIC economies could become as large as the G7 economies by $2032 .{ }^{2}$

At the same time, there is the opinion that BRICS countries face challenges at present and in the future. Some people ${ }^{3}$ say these challenges include the lack of global dynamism, important treaties are being negotiated but not all BRICS countries take part, changes in the process of production and commercialization of industrial products (global value chains) - this is particularly worrying, given the present competitive conditions in the international market for manufactures, taking, for instance, recent Latin American experiences. Others ${ }^{4}$ share the critical view that includes doubts about the very nature of the group; and there is also concern that the economic agenda of BRICS countries could pose new challenges to human rights and development, particularly given the absence of domestic frameworks for accountability on international engagements.

In any event, emerging powers themselves see their future in a deepened integration into the international system and globalization. ${ }^{5}$ We consider that the emergence of BRICS countries represents an important change in the global political economy. In this regard, one of the most significant and interesting developments in recent years has been the increasing cooperation between the BRICS countries in international competition policy.

Having started from different backgrounds, they have made remarkable progress in the creation of effective competition regimes and are attempting to develop their own local competition culture.

At present, all BRICS countries have modern competition regimes. As a common core serves the subject matter and declared goals of respective legal regulation, likewise it serves the common challenges BRICS countries face.

Thus, the general approaches taken by BRICS countries through their legislation and legal orders to counteract leading anticompetitive market strategies will be the subject matter of the present article.

The main idea of this article resides in the following. The analysis of substantial contents of the laws on competition and monopolies of the abovementioned BRICS

2 O'Neil J., Stupnytska A. The Long-Term Outlook for the BRICs and N-11 Post Crisis, 192 Goldman Sachs Global Econ. Paper 3 (2009), at <http://www2.goldmansachs.com/ideas/brics/brics-at-8/BRICS-doc. pdf> (accessed Jan. 6, 2014).

3 Baumann R. Seven Challenges to the BRICS (2013). Materials presented at the International Conference 'BRICS: perspectives of cooperation and development' held on behalf of the Ministry of Economic Development of the Russian Federation, Moscow (Dec. 5, 2013).

4 John L. Engaging BRICS. Challenges and Opportunities for Civil Society, 12 OIWPS (2012), <http://www. oxfamindia.org/sites/default/files/Working\%20paper\%2012.pdf> (accessed Jan. 10, 2014).

5 Seе: Концепция участия Российской Федерации в объединении БРИКС [Kontseptsiya uchastiya Rossiyskoy Federatsii v ob'edinenii BRIKS [Concept of the participation of Russia in BRICS]] (2013), <http://президент.pф/media/events/files/41d452a8a232b2f6f8a5.pdf> (accessed Jan. 14, 2013). 
countries and relevant case law shows the existence of a number of conventional, generally acknowledged (unified) provisions and norms. For example, we can name the following: forbidden anticompetitive actions and characteristics (indications) of abuse of a dominant position - fixing limits and price manipulations with regard to goods (services), carrying out discrimination between equal contractors, imposing on contractors additional (extra) goods and unreasonable conditions of contracts.

At the same time, economic concentrations by way of mergers \& acquisitions (M\&A) are a focus of the legislators of BRICS countries and meet the identical restriction of 'excessive' concentration. The existence of such a norm of an antimonopoly orientation, being caused by the current economic conditions, is justified in the countries that already have an effective economy, for example Russia and China, and it can promote an increase in efficiency, for example in India and South Africa. But in China and India it is a rare mechanism so far.

Thus the general approaches taken by BRICS countries through their legislation and legal orders to market structure control and restriction of anticompetitive M\&A will also be a focus as these forms are often used (along with others ${ }^{6}$ by transnational corporations (hereinafter TNCs). The steady growth in the transnationalization of the world economy reflected in increased international movement of capital, labor, technology, and information facilitates the implementation of strategies for the integration of entrepreneurial activities of the BRICS countries and the formation of TNCs through the transformation of national enterprises (legal entities, etc.), creating in the course of their activities subsidiaries abroad and acquiring shares of foreign enterprises in other ways.

On the one hand, these corporations have the nationality of the country in which they are established; on the other hand, by the nature of their interests and the scope of their activities they become international. TNCs have different ways of conducting their activities in other countries: from investments on the ground (e.g. the establishment of a completely new enterprise overseas) to delivering manufacturing plants to a host country through a system of mutual participation and joint ownership of companies, securities, etc.' Over the last decade TNCs have developed several standard methods of functioning in the national markets of a number of different countries, and one of them, one that creates preconditions

6 See in detail: Нарышкин C.E. и соавт. БРИКС: контуры многополярного мира [Narishkin S.E., et al. (ed.) [BRIKS: kontury mnogopoljarnogo mira [BRICS: the contours of the multipolar world]] 243-295 (The Institute of legislation and comparative law under the Government of the Russian Federation; Jurisprudence 2015); Беликова К. и соавт. Национальные особенности и перспективы унифиикации частного права стран БРИКС: учебник. В 2 m. [Belikova Ksenia, et al. (ed.) [Nacional'nye osobennosti i perspektivy unifikacii chastnogo prava stran BRIKS] [National characteristics and prospects for the unification of private law within the BRICS countries]] 220-302 (Moscow RUDN 2015).

Seе: Авдокушин Е.Ф., Жариков М.B. Страны БРИКС в современной мировой экономике [E.F. Avdokushin, M.V. Jarikov, Strany BRIKS v sovremennoj mirovoj jekonomike [BRICS countries in the modern world economy]] 27 (Moscow Magistr 2013). 
for facilitation of the implementation of global and regional governance, is proposed for consideration in this article.

Firstly, concentrations between undertakings can help increase economic scale, optimize resource allocation, and enhance the competitiveness of enterprises. Secondly, they may result in the decrease in the number of competitors. Particularly, when the concentration of undertakings reaches a level where undertakings can dominate or control a market, it may eliminate or restrict competition. Therefore, while stipulating that through the mechanisms of fair competition and voluntary alliance undertakings shall concentrate according to the law, thereby expanding the scope of operations and improving market competitiveness, the laws of the countries under study provide a system to control the concentrations between undertakings so as to prevent possible negative impacts on competition.

That is why we adhere to the following methodology of study:

- Acts. Scope of application and general provisions;

- Relevant case study

- with regard to:

1. Concept and general characteristics of sources of competition law within the legal orders of China, India, Russia, and South Africa with regard to abuse of dominance;

2. Criteria for establishment of a dominant market position fixed by Asian (China and India), Euro-Asian (Russia), and African (South Africa) legal orders and prohibition of abuse of market power;

3. Anticompetitive M\&As and market structure control realized by the responsible governmental bodies. General provision on restriction (control) of 'concentration' of enterprises' market power. Measures for the prevention and control of abuses of a dominant position in the market;

4. BRICS domestic competition authorities cross-border cooperation and interaction in the field under study.

\section{Discussion}

\subsection{General Characteristics of Sources of Competition Law Within the Legal Orders of China, India, Russia, and South Africa.}

China, Anti-Monopoly Law (AML) of the People's Republic of China of 2007 No. 68, adopted at the 29th meeting of the Standing Committee of the 10th National People's Congress of the PRC.

Before 1978, the Chinese economy could be characterized as a centrally planned economy. When the economic reform began in 1978 in China, a competition mechanism began to be introduced progressively. Since 1993 China has been developing a legal system for the socialist market economy and in that same year it enacted the Anti-Unfair Competition Law, its first fundamental law on the 
maintenance of the order of market competition. This law includes prohibitions against practices by undertakings having monopolistic status that restrict competition, administrative monopoly, selling goods at below-cost prices, tie-in sales, and bid rigging. Then, in August 2007, China promulgated the AML by drawing on the successful experience of foreign competition legislation and in line with the actual conditions in the country. The law prohibits monopoly agreements, abuse of dominant market position, anticompetitive concentrations between undertakings, and abuse of administrative power to eliminate or restrict competition. ${ }^{8}$

India, Competition Act of 2002, No. 12 of 2003, Acts of Parliament, 2002 (India).9 While the earlier Monopolies and Restrictive Trade Practices Act, 1969 had focused on curbing monopolies, the Competition Act, 2002 focuses on promoting competition. Keeping in view the economic development of the country, the Act provides for the establishment of a commission to prevent practices having an adverse effect on competition, to promote and sustain competition in markets, to protect the interests of consumers, and to ensure freedom of trade carried on by all market participants in India. ${ }^{10}$

Russia, Federal Law No. 135-FZ of 16 July 2006 On Protection of Competition (as amended in 2011). Under this Law, competition policy in the Russian Federation is carried out taking into account the practice of previous years, national economic priorities, and the production pattern that has been formed in the country. The proposed measures should contribute to enhancement of the efficiency of the bodies of state authority and local self-government in the conditions of the market economy, the development of competition in the Russian markets, and the increase in the competitive capacity of domestic producers."

South Africa, Competition Act No. 89 of 1998, § 3(1-2) (S. Afr.) (as amended in 2009). South Africa depends on direct foreign investment and thus has an interest in demonstrating to a prospective investor that it takes a proactive stand on fair competition and the preservation of economic freedom, though the South African economy is characterized by high levels of concentration in many sectors compared to other developing countries. The Reconstruction and Development Program, which was essentially the socio-economic policy framework in South Africa's first democratic government, had as one of its elements the promotion of competition as a remedy

8 Yang B. Chinese competition policy, 22 BLC 22: 25-31 (2006), at <http://ec.europa.eu/competition/ publications/blc> (accessed July. 10, 2013); Emch, Regazzini, et al. (eds.) Competition Law in the BRICS Countries 150 (Alphen aan den Rijn: Kluwer Law International 2012).

9 Available at <http://www.unctad.org/sections/ditc_ccpb/docs/ditc_ccpb_ncl_India_en.pdf > (accessed Feb. 3, 2014).

10 Мозолин В.П. Личность, право, экономика современной Индии [Mozolin V.P. Lichnost', pravo, jekonomika sovremennoj Indii [Personality, law, economy of modern India]] 167-171 (Moscow Nauka 1979). Regazzini Emch (note 9 above) at 101.

11 Federal Antimonopoly Service of Russia Report on Competition Policy in 2006 (2006). 
for excessive concentration and state control in the economy. The development of competition policy in South Africa should also be seen in the context of the shift towards trade liberalization, privatization, and deregulation that started under the apartheid government. Its key aims were to introduce effective competition into an economy that was expected to be governed by a smaller state and exposed to unprecedented levels of international competition. ${ }^{12}$

As we know, complicated legal terminology, uncertain and indistinct legal structures, unclear wording, and vague concepts, so-called 'rubber' (ambiguous, equivocal) structures and norms (e.g. public order), make it necessary to resort to case law (administrative and court decisions) as a means of interpretation and clarification of these concepts. Thus, case law takes on special significance as a source of ideas underlying competition policies.

Both doctrine (jurisprudence) and legislation of foreign countries provide the establishment of control of market behavior of enterprises (economic entities), forbidding anticompetitive agreements and abuses of a market dominant position, and monitoring market structure in order to prevent its distortion as a result of anticompetitive mergers \& acquisitions. Such a control is an essential part of a market strategy stimulated by the governments of all the countries under consideration. Let us look at it closer. And as for the presence or absence of internal (national) competition within BRICS countries, we should bear in mind that there is no place where we could find real competition. We should remember what conditional competition is. And we should be aware of the fact that a competitive economy is an ideal we all want to reach.

2.2. Criteria for Establishment of a Dominant Market Position Fixed by Asian (China and India), Euro-Asian (Russia), and African (South Africa) Legal Orders and Prohibition of Abuse of Market Power

The history of monopolization is inseparably linked with the development of the processes that at each stage accelerated the growth of monopolization of the economy, molding it into new forms. The most important of them are: the growth of the joint-stock company, the new role of banks and the development of a system of participation, monopolistic mergers as a way of centralization of capital, the evolution of forms of monopolistic association, and the newest forms of associations such as so-called multinational corporations (MNCs).

The Organization for Economic Cooperation and Development (OECD) defines MNCs as 'companies or other entities established in more than one country and so linked that they may coordinate their operations in various ways. ${ }^{\prime 3}$ The economic

12 Afrika S-L., Bachmann S-D. Cartel Regulation in Three Emerging BRICS Economies: Cartel and Competition Policies in South Africa, Brazil, and India - A Comparative Overview IL 45: 975-1003 (2011); Regazzini Emch (note 9 above) at 207.

13 OECD Guidelines for Multinational Enterprises, 3:14 (2008), <http://www.oecd.org/dataoecd/56/36/ 1922428.pdf> (accessed Jan. 1, 2014). 
impact of MNCs is quite significant and increasing: they operate in the form of multinational corporate groups organized in 'incredibly complex', multi-tiered corporate structures consisting of a dominant parent corporation, sub-holding companies, and scores or hundreds of subservient subsidiaries scattered around the world.

MNCs operate in different states, including emerging economies, through subsidiaries, branches, and alliances that may get involved in cartel and market dominance activities. That is why business activities of MNCs with their headquarters registered in the developed world are often subject to strict competition or antitrust laws. ${ }^{14}$

Abuse of dominant market position, a typical monopolistic practice, is regulated by antitrust laws in many countries and regions.

China's Anti-Monopoly Law, 2007 regulates such abuse, including the concept, definition, and determination of a dominant market position, and the category and legal liabilities of abuses of dominant market positions.

A precondition for abuse of 'dominant market position' is that, of course, the undertaking has such a position. Therefore, it is very important to define this term, which, according to the AML, is as follows: 'dominant market position refers to a market position held by a business operator [undertaking] having the capacity to control the price, quantity or other trading conditions ... in a relevant market, or to hinder or affect any other business operator to enter the relevant market' (Art. 17 AML, Ch. 3).

Abuse of dominant position according to Article 17 of AML 2007 consists in:

'(1) selling commodities at unfairly high prices or buying commodities at unfairly low prices;

(2) selling products at prices below cost without any justifiable cause;

(3) refusing to trade with a trading party without any justifiable cause;

(4) requiring a trading party to trade exclusively with itself or trade exclusively with a designated business operator(s) without any justifiable cause;

(5) tying products or imposing unreasonable trading conditions at the time of trading without any justifiable cause;

(6) applying dissimilar prices or other transaction terms to counterparties with equal standing;

(7) other ... [conduct] determined as abuse of a dominant position by the Antimonopoly Authority under the State Council.'

As we can see, the list of illegal actions a dominant position can express - is not exhaustive.

Article 18 of AML 2007 specifies the factors according to which the dominant market position shall be determined: '(1) the market share of a business operator

14 Afrika S-L., Bachmann S-D. (note 15 above) at 975-1003. 
in [the] relevant market, and the competition situation of the relevant market; (2) the capacity of a business operator to control the sales markets or the raw material procurement market [market power, in other words]; (3) the financial and technical conditions of the business operator; (4) the degree of dependence of other business operators ... [on] the business operator in transactions; (5) the degree of difficulty for other business operators to enter the relevant market; and (6) other factors related to ... [determining] a dominant market position of the said business operator.'

Also according to the AML, a'relevant market' refers to the product or geographic dimensions of the market within which undertakings compete with each other regarding particular products or services during a certain period of time. The detailed definition of relevant markets is provided in the Guidelines on definition of Relevant Market issued by the Anti-Monopoly Commission under the State Council, May 2009..$^{15}$

Article 19 of AML 2007 provides for the circumstances that prima facie prove an undertaking may be assumed to have a dominant market position. They are: '(1) the relevant market share of a business operator accounts for $1 / 2$ or above in the relevant market; (2) the joint relevant market share of two business operators accounts for $2 / 3$ or above; or (3) the joint relevant market share of three business operators accounts for $3 / 4$ or above. A business operator with a market share of less than $1 / 10$ shall not be presumed as having a dominant market position even if they fall within the scope of [the] second or third item.'

This approach agrees closely with the ideas expressed in the Annual report of the EU Commission of 1980, where it was confirmed that an enterprise can be considered dominant if it holds a $40-45 \%$ market share, for enterprises occupying $20-40 \%$ of the market the possibility is less likely, and those possessing $10 \%$ market share - never can be deemed dominant. ${ }^{16}$

At the same time, Article 19 provides (like the South African legal order) a refutable presumption of a dominant market position: 'Where a business operator who has been presumed to have a dominant market position can otherwise prove that they do not have a dominant market, it shall not be determined as having a dominant market position.'

Since the AML took effect in 2008 , quite a number of private actions have been filed with the Chinese courts. To date, all of the reported cases have been stand-alone actions and most of them challenged alleged abuse of dominance. In those abuse of dominance cases where judgments were rendered, the claims were all dismissed because of the plaintiffs' failure to define the relevant markets or their failure to prove the existence of a dominant position or the actual abuse of dominance.

15 Yang B. (note 9 above).

16 Figari H., Gomez H., Zuniga M. Hacia una metodología para la definición del Mercado relevante y la determinación de la existencia de posición del dominio, 2 RCPI 153-187 (2005). 
For example, in the first judgment - Sursen v. Shand $a^{17}$ - delivered in an antitrust lawsuit in China, the Shanghai Intermediate People's Court rejected an abuse of dominance action brought by Beijing Sursen Electronic Technology Co., Ltd (Sursen), an online literature website operator, against Shanda Interactive Entertainment Ltd (Shanda). Sursen alleged that Shanda had abused its dominant position in the market for online literature by forcing two authors to stop writing for Sursen a sequel to a popular online novel published by Shanda, and thus violated the prohibition on requiring exclusive dealings under the AML. Sursen adduced Shanda's marketing documents in order to prove Shanda's dominant position, but the court held that the evidence was insufficient to prove that Shanda held a dominant position in the relevant market.

In the case Li Fangping v. China Netcom, Li Fangping, a customer of China Netcom, accused China Netcom of abuse of dominance by engaging in discriminatory treatment. Li alleged that when applying for installation of landline phones with China Netcom, post-pay contracts were only available for permanent Beijing residents or nonpermanent residents who own real estate in Beijing, have been prepay customers for one year or provide a guarantee. The court found that there was a relatively high degree of substitutability between landline and mobile telephony services and between cable and wireless Internet services. The court dismissed Li's claim because of insufficient evidence of dominance presented. In addition, the court held that China Netcom's policies for post-pay landline telephony were justified because of the need to control credit risks. ${ }^{18}$

As for India, dominance as a concept refers to the exploitation of market power or employing improper means to maintain such market power by a single firm, and the provisions of the Competition Act, 2002 seek to promote and ensure fair competition by prohibiting activities that raise competition concerns in the relevant market to the prejudice of the consumer in such a way (Sec. 4(1)). The Act also attempts to prohibit abuse of dominance by enterprises or groups, and it lists conduct which is considered to cause an appreciable adverse effect on competition in India (Sec. 4(2)).

Unlike the erstwhile Monopolies and Restrictive Trade Practices Act, 1969, the 2002 Act does not seek to regulate dominant position (i.e. big is bad) and instead prohibits the abuse of dominant position. Therefore, the Act seeks to regulate only abuse of dominance by dominant enterprises under Section 4 and not dominant enterprises that are not abusing dominance as provided under the erstwhile legislation.

Section 4 of the Act prohibits the abuse of dominant position by any'enterprise' or 'group', as was mentioned above. An enterprise, as defined under the Act, includes all its divisions, units, and subsidiaries. A group, for the purposes of abuse of dominance cases, means 'two or more enterprises, which directly or indirectly are in a position to:

\footnotetext{
17 Regazzini, Emch (note 9 above) at 189.

18 Id. at $189-190$.
} 
(a) exercise $26 \%$ or more of the voting rights in the other enterprise; or

(b) appoint more than $50 \%$ of the members of the board of directors in the other enterprise; or

(c) control the management or affairs of the other enterprise.'

Therefore, only an enterprise or a group can be considered dominant. Where two or more enterprises together engage in uniform conduct raising competition concerns, this may not be considered by the Commission under the provisions of the Act. Thus, unlike the law in the European Union, ${ }^{19}$ on which the Act is largely based, there is no concept of collective dominance under the Act. Consequently, abuse of dominance is limited to an enterprise or group thereof (i.e. related entities) and not independent entities (two or more) which may together be considered to be dominant in the relevant market. Any conduct aimed at ensuring collective dominance can be captured under the anti-cartel provisions of the Act.

India's Competition Act of 2002 prohibits in its Section 4 abuse of dominant position, which, according to the sense of the law, takes place when an enterprise or a group:

'(a) directly or indirectly, imposes unfair or discriminatory

(i) condition in purchase or sale of goods or service; or

(ii) price in purchase or sale (including predatory price) of goods or service.

... For the purposes of this clause, the unfair or discriminatory condition in purchase or sale of goods or service referred to ... [above] ... shall not include such discriminatory condition or price which may be adopted to meet the competition; or

(b) limits or restricts

(i) production of goods or provision of services or market therefor; or

(ii) technical or scientific development relating to goods or services to the prejudice of consumers; or

(c) indulges in practice or practices resulting in denial of market access (in any manner); or

(d) makes conclusion of contracts subject to acceptance by other parties of supplementary obligations which, by their nature or according to commercial usage, have no connection with the subject of such contracts; or

(e) uses its dominant position in one relevant market to enter into, or protect, other relevant market.'

At the same time, 'dominant position' means a position of strength, enjoyed by an enterprise, in the relevant market, in India, which enables it to (i) operate independently of competitive forces prevailing in the relevant market; or (ii) affect its competitors or consumers or the relevant market in its favour' (Sec. 4).

19 Whish R., Sufrin B. Competition Law 281 (2d ed. Butterworths, London 1993). See also: Abuse of dominance and monopolization. OCDE/GD(96) 131 (1996). <http://www.oecd.org/dataoecd/0/61/2379408.pdf> (accessed Aug. 4, 2010). 
According to Section 54,'[T] he Central Government may, by notification, exempt from the application of this Act, or any provision thereof, and for such period as it may specify in such notification (a) any class of enterprises if such exemption is necessary in the interest of security of the State or public interest; (b) any enterprise which performs a sovereign function on behalf of the Central Government or a State Government.'

Also, along with Section 2, which gives the definitions of the principal words and expressions used in the Act, the Act'does not include any activity of the Government relatable to the sovereign functions of the Government including all activities carried on by the departments of the Central Government dealing with atomic energy, currency, defence and space.'Thus, these enterprises can be monopolies and are able, theoretically, to abuse their market position.

South Africa's Competition Act No. 89 of 1998 (as amended) uses the same legal techniques as the Indian Act.

Abuse of dominance is determined with terms similar to those used in the Indian legislation. Section 8 states: 'It is prohibited for a dominant firm to -

(a) charge an excessive price to the detriment of consumers;

(b) refuse to give a competitor access to an essential facility when it is economically feasible to do so ...,' but the domination is predisposed by a market share.

'Thus, a firm is dominant in a market if -

(a) it has at least $45 \%$ of that market;

(b) it has at least $35 \%$, but less than $45 \%$, of that market, unless it can show that it does not have market power; or

(c) it has less than $35 \%$ of that market, but has market power' (Sec. 7, Ch. 2).

At the same time, according to Section 10 of the Act a firm may apply to the Competition Commission to exempt from the application of Chapter 2 -

(a) an agreement or practice, if that agreement or practice; or

(b) category of agreements or practices, if that category of agreements or practices, if the agreement or practice concerned, or category of agreements or practices concerned, contributes to any of the following objectives:

'(i) maintenance or promotion of exports;

(ii) promotion of the ability of small businesses, or firms controlled or owned by historically disadvantaged persons, to become competitive;

(iii) change in productive capacity necessary to stop decline in an industry; or

(iv) the economic stability of any industry designated by the Minister, after consulting the Minister responsible for that industry' (Sec. 10(3)).

As for the abuse of dominance, the Act provides for: (a) 'a threshold of annual turnover, or assets, in the Republic, either in general or in relation to specific industries, below which the provisions of the Part B' - Abuse of a Dominant Position do'not apply to a firm' (i.e. a person, a partnership, trust); and for (b)'a method for the calculation of annual turnover or assets' to be applied in relation to that threshold - 
to be determined by the Minister, in consultation with the Competition Commission (Sec. 6(1)). Before making a determination, the Minister, in consultation with the Competition Commission, must publish in the Gazette a notice:

(a) setting out the proposed threshold and method of calculation for purposes of this section;

(b) and inviting written submissions on that proposal (Sec. 6(3)).

The Competition Tribunal has found that abuse occurred in six cases: on the part of Patensie (37/CR/Jun01), South African Airways (twice - 80/CR/Sep06 and 18/CR/ Mar01), Sasol (72/CR/Dec03), Mittal Steel SA (13/CR/Feb04), and Senwes (110/CR/ Dec06). ${ }^{20}$ However, in the Sasol case the finding was overturned (49/CAC/Apr05), and in the Mittal Steel case (43/CAC/Nov04) the finding was set aside and remitted by the Competition Appeal Court. In the Senwes matter (118/2010), an appeal against the Competition Tribunal's finding was upheld by the Supreme Court of Appeal on procedural grounds. The Constitutional Court has recently set the Supreme Court of Appeal's ruling aside (CCT 61/11). The Constitutional Court found that the Supreme Court of Appeal erred when it held that the referral did not cover the complaint in which Senwes was found to have contravened the relevant section of the Competition Act.

The early abuse cases at the Competition Tribunal included considerations of excessive pricing in the Harmony/Mittal matter, in which the Competition Tribunal found Mittal to be charging excessive prices. However, the Appeal Court remitted the matter to the Competition Tribunal for reconsideration as it ruled that the Competition Tribunal had not interpreted the excessive pricing provision of the Act correctly (although the Court did find that there was a prima facie case for excessive pricing).

Early abuse cases also tested certain exclusionary abuse provisions of the Act, such as inducement in the South African Airways case, and impact of exclusionary conduct in the BATSA case (55/CR/Jun05).

As for Russia, Law No. 135-FZ of 16 July 2006 On Protection of Competition embraces key provisions on dominant market position of the previous Law No. 948-1.

Dominant position is recognized when the position of an economic entity (a group of persons) or several economic entities (groups of persons) in the market of a certain commodity gives the economic entity or entities an opportunity to have a decisive impact on the general conditions of commodity circulation in the relevant goods market and (or) to remove other economic entities from this goods market and (or) to impede access to this goods market for other economic entities (Art. 5(1)).

At the same time, the Law on Protection of Competition in force changed a threshold starting at which an economic entity is considered to be dominant just on

20 Regazzini, Emch (note 9 above) at 212. 
the basis of its market share - from $65 \%$ to $50 \%$. It was also made clear that dominant position can be declared by a state authority - the Federal Antimonopoly Service (FAS) of the Russian Federation - when: (1) a case on violation of antimonopoly legislation is considered or (2) a control on economic concentration is exercised.

Similarly, establishment of the existence of circumstances under which the economic entity with market share that exceeds $50 \%$ will not be considered dominant is the exclusive competence of the Antimonopoly Authority, considering that the economic entity can provide the Antimonopoly Authority or Court with proof that such a position of the economic entity is not dominant.

The new 2006 Law also contains the provisions of the previous Law No. 948-1, according to which an enterprise with market share of $35 \%$ cannot be considered dominant. This provision has two exemptions. The first concerns cases in which an enterprise that has less than $35 \%$ of the market can be deemed dominant by other federal laws (e.g. in the markets with state regulation of price-forming, tariffs, outputs, power, zones of service, etc.). The second is with regard to oligopolistic markets. Thus, the law defines that dominant position can refer to the company: (1) with market share less than $35 \%$ if there is a stable kernel of the largest companies in this market (e.g. there are two to five companies with market share from $50 \%$ to $70 \%$ ); (2) if the company products are unique and have no substitutes, and the consumer is not able to reduce the consumption of these products, in spite of price growth; (3) if access by new sellers (players) into the market is complicated, and the prices and other conditions of sale of goods established by the company are freely accessed (e.g. via the Internet). This approach is close to the approach, already existing for a long time, in the enforcement practices of the European Union. ${ }^{21}$

An economic entity with a dominant market position is prohibited from abusing its market power by way of:

21 Байда А.Г. Правовые аспекты доминирующего положения предпринимателя в Европейском Союзе. In: Материалы семинара «Преподавание права Европейского Союза в российских ВУЗах - I॥, состоявшегося в Москве 5-7 декабря 2000 г. [Bayda A.G. Pravovye aspekty dominirujushhego polozhenija predprinimatelja $v$ Evropejskom Sojuze [Legal aspects of dominant position of businessmen in the European Union]]. In: Materials of the seminar 'Teaching European Union law at the Russian Universities - II' (Dec. 5-7, 2000, Moscow) 174-190 (Moscow, Statut 2001)]; Беликова К.М. Злоупотребление доминирующим положением в законодательстве, доктрине и правоприменительной практике Европейского Союза и стран Южноамериканского общего рынка - Аргентины, Бразилии и Перу, 7(79) Право и политика 38-52 (2006) [Belikova K.M. Zloupotreblenie dominirujush him polozheniem v zakonodatel'stve, doktrine i pravoprimenitel'noj praktike Evropejskogo Sojuza i stran Juzhnoamerikanskogo obshhego rynka - Argentiny, Brazilii i Peru, 7(79) Pravo i politika 38-52 (2006) [Belikova K.M. Abuse of a dominant position in the legislation, doctrine and practice of the European Union and the countries of the southern common market - Argentina, Brazil and Peru, 7(79) Law and politics 38-52 (2006)]]; Сушкевич А.Г. Правовая квалификация доминирующего положения в новом антимонопольном законодательстве, 2 Закон 25-29 (2008) [Sushkevich A.G. Pravovaja kvalifikacija dominirujushhego polozhenija v novom antimonopol'nom zakonodatel'stve, 2 Zakon 25-29 [Sushkevich A.G. Legal qualification of dominant position in new antimonopoly legislation, 2 Zakon 25-29 (2008)]]. 
1) establishment and maintaining of a monopolistically high or monopolistically low price for a commodity;

2) withdrawal of goods from circulation, if the result of such withdrawal is increase of price of the commodity;

3) imposing contractual terms upon a counter-agent which are unprofitable for said agent or not connected with the subject of agreement (economically or technologically unjustified);

4) economically or technologically unjustified reduction or cutting off the production of goods if there is demand for the goods or orders for their delivery are placed and there is the possibility of their profitable production, as well as if such reduction or cutting off the production of goods is not provided for directly by the Federal Laws, etc.;

5) economically or technologically unjustified refusal or evasion from concluding a contract with individual purchasers (customers) in the case where there are possibilities for production or delivery of the relevant goods as well as if such a refusal or evasion is not provided for directly by the Federal Laws, etc.;

6) economically, technologically or otherwise unjustified establishment of different prices (tariffs) for the same goods if not established otherwise by the Law;

7) establishment of an unjustifiably high or unjustifiably low price of a financial service by a financial organization;

8) creation of discriminatory conditions;

9) creation of barriers to entry into the goods market or to exiting from the goods market for the other economic entities;

10) violation of the procedure of pricing established by statutory legal acts;

11) manipulating prices on wholesale and (or) retail markets of electric power (capacity - Art. 10 Law No. 135-FZ 2006).

As for the features of the 2006 Law, it is worth mentioning that it contains a complicated system of exceptions from prohibitions on different types of monopolistic activities (e.g. Art. 13).

Enforcement practice proves that most often markets that become an object of the relevant court proceedings are markets for oil products, coal, housing services (e.g. elevators, repair works, storage of domestic waste, maintenance of gas equipment), rail and air transportation, airport activities, the power industry, communications services. Rarer, but also rather regularly, courts intervene in the markets for the services of warehouses for temporary storage and also in the markets for the production of bakery products. ${ }^{22}$ And the question of a definition for geographical and product boundaries of the market is still a serious problem

22 Тай Ю. Судебная практика по делам о злоупотреблении доминирующим положением, 1 Корпоративный юрист 10-12 (2012) [Taj Ju. Sudebnaja praktika po delam o zloupotreblenii dominirujushhim polozheniem, 1 Korporativnyj jurist 10-12 (2012) [Taj Ju. Case law on abuse of a dominant position, 1 Korporativnyj jurist 10-12 (2012)]]. 
(e.g. law-enforcement bodies tend to narrow geographical boundaries of the market).

Thus, transformation of retail trade into large trade networks (retailers) allowed the latter, despite their seemingly small market share, to dictate the rules of the game and determine the network entry conditions for suppliers and producers. Such influence of retailers on competition is explained by growing volumes of production and imported goods coupled with the deficit of trading outlets as well as the similarity of relationship practices between retailers and suppliers.

Some of the abusive practices of retailers include: charging suppliers for access to the retailers' network of stores; imposing pricing policy on suppliers; unilateral failure to fulfill contract obligations and unilateral termination of supply contracts; and suppliers' compensation of losses caused by theft in the retailers' trading outlets. ${ }^{23}$

The representative case in the field of suppressing abuses of market dominance is the sulfur market case. The main producers of sulfur in the Russian Federation are companies that also have connections with Gazprom OJSC, with over $50 \%$ share of the market in liquid sulfur. In March 2011 the price for liquid sulfur increased $246 \%$ over the price of the previous month, and the growth continued throughout 2011. Gazprom OJSC was fixing sulfur prices in accordance with a devised formulae for calculations that depended on the world prices for sulfur and diammonium phosphate, and some coefficients.

A FAS Commission concluded that the global prices for diammonium phosphate and the application of increasing coefficients depending on the world prices for this type of phosphorus-containing fertilizers did not affect the costs of sulfur production and the conditions of its sales in the domestic market, and could not be used to calculate the price. FAS imposed an administrative fine on Gazprom OJSC for fixing monopolistically high prices - a fine amounting to RUB 17,525,592.8 (around US\$ 550,000). The court supported the FAS decision. ${ }^{24}$

\subsection{Anticompetitive M\&As and Market Structure Control Realized by the Responsible Governmental Bodies. General Provision on Restriction (Control) of 'Concentration' of Enterprises' Market Power}

China's AML 2007 provides a system to control the concentrations between undertakings so as to prevent possible negative impacts on competition (Arts. 2327, 31 and others of AML 2007). This law does not specifically define the term 'concentration between undertakings'. Instead, it lists several concentration scenarios, including:

1) merger of undertakings;

${ }^{23}$ Federal Antimonopoly Service of Russia. Russia's activities on developing competition in retail (2007).

24 Federal Antimonopoly Service of Russia Report on competition policy in 2012 (2012). 
2) control over other undertakings gained by an undertaking through acquiring their shares or assets; and

3) control over other undertakings or the ability to exert a decisive influence on the same gained by an undertaking through a contract or other means (Art. 20).

Once a concentration between undertakings adverse to market competition is completed, it will cost a great deal to rectify it. Therefore, the AML provides a system of pre-closing notification. Indeed, when their intended concentration reaches the threshold level as set by the State Council, undertakings shall notify in advance the Anti-monopoly Authority (AMA) under the State Council (Art. 21); they shall not implement the concentration in the absence of such notification.

The following documents and materials should be submitted:

1) a declaration paper;

2) explanations on the effect of the concentration on the relevant market competition;

3) the agreement of concentration;

4) the financial reports and accounting reports of the proceeding accounting year of the business operator; and

5) other documents and materials as stipulated by the AMA under the State Council (Art. 23).

But in any of the following circumstances, undertakings may dispense with such a notification:

1) one of the undertakings involved in the concentration owns $50 \%$ or more of the voting shares or assets of each of the other undertakings; or

2) one and the same undertaking not involved in the concentration owns 50\% or more of the voting shares or assets of each of the other undertakings involved in the concentration.

At the same time, according to the Thresholds 'Reg', concentrations between business operators are subject to mandatory notification requirements if:

- the combined aggregate worldwide turnover of all parties to the concentration in the last financial year was more than RMB (Yuán) 10 billion (approximately US\$ 1.6 billion $^{25}$ ) and the turnover within China of each of at least two parties to the concentration in the last financial year was over RMB 400 million (approximately US\$ 63.5 million); or

- the combined aggregate Chinese turnover of all parties to the concentration in the last financial year was more than RMB two billion (approximately US $\$ 317.4$ million) and the Chinese turnover of each of at least two parties to the concentration in the last financial year was over RMB 400 million (approximately US $\$ 63.5$ million). ${ }^{26}$

\footnotetext{
25 Exchange rate used: US\$ $1=$ RMB 6.3009 (average rate on Dec. 30, 2011) from People's Bank of China.

26 Regazzini, Emch (note 9 above) at 197.
} 
Where the AMA under the State Council decides to conduct further review, it shall, within 90 days from the date of the decision, complete the review, make a decision on whether to prohibit the concentration, and notify the business operators concerned of the decision in written form (Art. 26).

Estimating the compatibility of the concentration with the market, the AMA takes into account:

1) the market share of the business operators involved in the relevant market and the controlling power thereof over that market,

2) the degree of market concentration in the relevant market,

3) the influence of the concentration of business operators on market access and technological progress,

4) the influence of the concentration of business operators on consumers and other business operators,

5) the influence of the concentration of business operators on national economic development, and

6) other elements that may have an effect on market competition (Art. 27).

If the business operators concerned can prove that the concentration will have more positive impact than negative impact on competition, or the concentration is pursuant to public interests, the AMA under the State Council may decide not to prohibit the concentration (Art. 28).

By March 10, 2012, 13 decisions had been published, including 12 conditional approvals and one prohibition. Out of those 12 conditional approvals, only two cases (InBev/Anheuser-Busch in 2008 and General Motors/Delphi in 2009) were decided within the first phase. The other 10 cases were decided somewhere during the second phase or the extended period of the second phase (90-day review).

Merger review in India is governed by the Competition Act, 2002. Sections 5 and 6 of the Act are the focal provisions dealing with merger review in India. Section 5 prescribes worldwide Indian assets and turnover thresholds for transactions involving the acquisition of an 'enterprise' or mergers and amalgamations of enterprises.

'The acquisition of one or more enterprises by one or more persons or merger or amalgamation of enterprises shall be a combination of such enterprises and persons or enterprises' (italics added), if the operation parties fall under the legal provisions containing certain numerical indicators specified in Article 5 of the Competition Act, 2002, addressed to the enterprises (persons).

Thus, any acquisition is considered to be monopolistic where, for instance, 'the parties to the acquisition, being the acquirer and the enterprise, whose control, shares, voting rights or assets have been acquired or are being acquired jointly have,

(A) either, in India, the assets of the value of more than rupees one thousand crores or turnover more than rupees three thousand crores; or

(B) in India or outside India, in aggregate, the assets of the value of more than five hundred million US dollars, including at least rupees five hundred crores in India, 
or turnover more than fifteen hundred million US dollars, including at least rupees fifteen hundred crores in India, etc.' (Sec. 5, Competition Act, 2002).

The substantive test used to assess combinations is set out in Section 6. Domestic and international acquisitions, mergers or amalgamations (referred to as 'combinations') are required to give notice to the Competition Commission of India (CCl). This section prohibits combinations which cause or are likely to cause'an appreciable adverse effect on competition within the relevant market in India' and treats such combinations as void. And'no combination shall come into effect until two hundred and ten days have passed from the day on which the notice has been given to the Commission' (Sec. 6).

In addition to the aforementioned provisions of the Act, the $\mathrm{CCl}$ issued the $\mathrm{CCl}$ Regs, 2011 Combination 'Reg' (the procedure in regard to the transaction of business relating to combinations), setting out the scheme for implementing the merger control provisions under the Act. Despite the fact that the Combination 'Reg' had been in force for less than a year, the $\mathrm{CCl}$ introduced amendments by way of the $\mathrm{CCl}$ Amendment 'Reg' published on 23 February 2012, which partially addressed the concerns of industry. ${ }^{27}$

To date, the $\mathrm{CCl}$ has passed orders in 28 combinations (of which 15 relate to intragroup reorganizations) within the prescribed statutory time limit of 30 days. The $\mathrm{CCI}$ completed its first merger control review (C-2011/07/01) relating to an acquisition from the Bharti Group of a 74\% equity interest in two joint venture companies, Bharti AXA Life Insurance Ltd and Bharti AXA General Insurance Ltd, by the Indian conglomerate Reliance Industries Ltd.

Taking into account the relatively low market shares of the parties and the fact that there was no horizontal or vertical overlap between the parties, the $\mathrm{CCl}$ granted its approval within a relatively short period of 18 days from the notification.

The stated purpose of the South African competition law encompasses orthodox concerns related to efficiency, prices, and choice. In addition, the statute also articulates the purpose of the Competition Act, 1998 as promoting competition in order to realize goals related to employment creation and retention, equitable participation in the economy by small and medium-sized enterprises, a broader and more racially diverse spread of ownership, and international competitiveness. The 1998 Act thus envisions a role for the competitive process in rectifying the distortions and inequities wrought on the economy and society by the apartheid regime. Both these strands in the legislation ultimately relate to the government's economic, development, and social policies.

The 1998 Act makes provision for a system of compulsory merger notification. Mergers can be of the same kind:

(a) 'a small merger' means a merger or proposed merger with a value at or below the lower threshold established in terms of 'sub-s[ection] (1)(a)';

\footnotetext{
27 Regazzini, Emch (note 9 above) at 134.
} 
(b) 'an intermediate merger' means a merger or proposed merger with a value between the lower and higher thresholds established in terms of 'sub-s (1)(a)'; and

(c) 'a large merger' means a merger or proposed merger with a value at or above the higher threshold established in terms of'sub-s (1)(a)' (Sec. 11(5)).

As for this threshold

(a) A lower and a higher threshold of combined annual turnover or assets, or a lower and a higher threshold of combinations of turnover and assets, in the Republic, in general or in relation to specific industries, for purposes of determining categories of mergers contemplated in 'sub-s (5)'; and

(b) a method for the calculation of annual turnover or assets to be applied in relation to each of those thresholds must be determined by the Minister, in consultation with the Competition Commission (Sec. 11(1)).

For large or intermediate mergers, as determined by thresholds stipulated by 'Regs' issued by the Minister of Economic Development, notice must be given to the Competition Commission (CC); while notice in respect of small mergers may be given voluntarily or as required by the CC.

The CC issues decisions in respect of small and intermediate mergers and provides recommendations to the Competition Tribunal in respect of large mergers.

A merger occurs when one or more firms directly or indirectly acquire or establish direct or indirect control over the whole or part of the business of another firm. Mechanisms of acquiring control are the following: (i) purchase or lease of the shares, an interest or assets of the other firm in question; or (ii) amalgamation or other combination with the other firm in question (Sec. 12(1)).

The CC can attach conditions to mergers if it believes that they will address significant public interest or competition concerns. These conditions could include structural remedies, such as divestiture of businesses, or behavioral remedies, such as supply obligations, or conditions addressing public interest concerns. Merger proceedings may include the submissions of a broad range of stakeholders, such as government, labor, consumer groups, and small business, which need to be taken into consideration in decision-making.

If it is possible that the merger is likely to substantially prevent or lessen competition, then, based on the 'rule of reason', the Commission should assess, among others, the following factors:

'(i) whether or not the merger is likely to result in any technological, efficiency or other pro-competitive gain which will be greater than, and offset, the effects of any prevention or lessening of competition, that may result or is likely to result from the merger, and would not likely be obtained if the merger is prevented; and

(ii) whether the merger can or cannot be justified on substantial public interest grounds, by assessing the following factors ... :

... a particular industrial sector or region;

... employment; 
... the ability of small businesses, or firms controlled or owned by historically disadvantaged persons, to become competitive; and

... the ability of national industries to compete in international markets.'

Thus, generally speaking, public interest considerations are reflected in the merger assessment provisions, which require the authority to determine whether or not a merger can be justified on substantial public interest grounds (Sec. 12A).

As for Russia, procedures on control of economic concentration in the Russian Federation are turned over to coordination by (consent of) the Antimonopoly Authority of a number of transactions and market actions provided in Article 7 of the Law On Protection of Competition, 2006 with regard to, first, certain criteria indicating the types of transactions and market actions and, second, cases subject to consent.

The following actions shall only be performed with the antimonopoly body's prior consent:

- the merger, acquisition or establishing of a commercial organization (the latter if its capital is paid by stocks (shares) and (or) property that are the main productionrelated assets and (or) intangible assets of another commercial organization Art. 27(1)(div.1)2)4)5) Law 2006);

- the merger of a financial organization merging with a commercial organization and vice versa (Art. 27(1)(div.6)7) Law 2006);

- the acquisition by a person (or a group of persons) of voting stocks of a jointstock company or shares in the authorized capital of a limited liability company (Art. 28(1)(div.1-6) Law 2006);

- obtaining by an economic entity (a group of entities) of fixed production assets (except plots of land and non-industrial buildings, structures, installations, premises and parts of premises, incomplete construction facilities) and (or) non-material assets of another economic entity registered in the Russian Federation (with the exception of a financial organization) (Art. 28(1)(div. 7) Law 2006).

At the same time, the requirement on receiving the prior consent of the Antimonopoly Authority on a number of transactions and market actions does not apply in some cases, for example:

- if the actions specified in part 1 of the present article (28) are carried out by the persons entering one group of persons on the bases provided by the provisions of division 1 of part 1 of Art. 9 of the present Federal Law (2006), or

- if their implementation is provided by acts of the President of the Russian Federation or acts of the Government of the Russian Federation, etc. (Art. 27(2) Law 2006).

The criteria of an assessment of the compatibility of economic concentration and a market thus designated above have a complex character. For example, one of such criteria, enshrined in Articles 27 and 28 of the 2006 Law, is the aggregate revenues from the sale of commodities in accordance with the accounting balance sheets as of the latest reporting date. 
Additional criteria can be mentioned, for example:

- for transactions on acquisition of voting stocks of a joint-stock company (JSC), similar to Private Company or Closely Held Corporation in common law countries (UK, USA, etc.) - a certain percent of the stocks;

- for transactions on acquisition of a certain value of the volume of shares in the authorized capital of a limited liability company.

Article 30 of the 2006 Law names the types of transactions and market actions subject to prior or post (subsequent) control.

In general, it is necessary to point out that the institute of control of economic concentration practiced by the Russian Federation Antimonopoly Service is the main form of the prevention of abuses by the dominant position.

Thus, in 2012 FAS considered 2,494 pre-merger notifications and 1,943 postmerger notifications from economic entities: it granted 2,449 pre-merger notifications (of which 229 with issuing determinations) and 1,933 post-merger notifications; it refused 45 pre-merger notifications and 10 post-merger notifications.

As for typical cases, to name a few:

1. Approval of pre-merger notifications. FAS analyzed the wholesale market of granite macadam due to investigating a pre-merger notification of National NonMetallic Company, OJSC (NNK; similar to Public Company or Openly Held Corporation in common law countries about acquiring $100 \%$ voting shares of Pavlovskgranit OJSC as well as a pre-merger notification of NNK on acquiring $75 \%$ voting shares of First Non-Metallic Company OJSC (PNK). (Informational note: FAS used the data from these companies and other sources; the time interval of the study was 2011-2012.)

Having researched the wholesale market for granite macadam, FAS identified signs of Pavlovskgranit OJSC having the dominant position within the boundaries of the Central Federal District. FAS granted NNK the pre-merger notifications on acquiring $100 \%$ voting shares of Pavlovskgranit OJSC and $75 \%$ voting shares of PNK. Both decisions were accompanied by determinations, the second one contained structural remedies.

2. Granting of a pre-merger notification. In 2012, FAS considered a petition on acquiring $70 \%$ of the statutory capital of BNP Pariba Vostok Commercial Bank Ltd by the Savings Bank of Russia OJSC.

Having made the necessary calculations, FAS concluded that despite the Savings Bank of Russia OJSC possibly having a dominant position in the regional markets of banking services, acquiring $70 \%$ of the statutory capital of BNP Pariba Vostok Commercial Bank Ltd would not restrict competition in these markets and in the market for factoring services in view of the specifics of the transaction.

3. Dismissal of a pre-merger notification. FAS dismissed a pre-merger notification by Gazprombank OJSC for acquiring 50.9\% voting shares of Moscow Integrated Grid Company OJSC in trust management because the transaction in question would 
result in combining activities for transmitting electric power with electric power generation by legal entities affiliated with Gazprom OJSC. ${ }^{28}$

Thus, it is established that legislation of the BRICS countries under study reacts identically on the concentration of capital by means of mergers \& acquisitions. And the purpose of the practiced state control consists, naturally, not so much in forbidding operations on concentration as, on the contrary, in stimulating mergers, associations of the national enterprises for strengthening of their competitiveness in the world market.

As we know, on the national level the most fundamental step that had already been taken by policymakers worldwide (and BRICS countries are not an exception) to embrace a more market-based economy was to build a competition culture.

It is conventional wisdom that for an effective competition regime a competition agency must do more than simply enforce the competition law. It is important for competition agencies especially in developing countries to engage in competition advocacy and awareness generation. And this idea is worth special mentioning with regard to M\&As in the BRICS countries under study. Let us look at several examples.

\subsection{BRICS Domestic Competition Authorities Cross-Border Cooperation and Interaction}

In Russia, for instance, under the Federal Antimonopoly Service the Public Advisory Board (Council), embracing representatives of the most influential noncommercial associations and business associations, is in full operation. The Council monitors the activities of FAS and develops recommendations on improvements to antitrust law and policies and enforcement of suppression of their violation. Councils are formed and operate in the territorial offices of FAS. Simultaneously, under FAS, Advisory Councils (AC) on the key markets (e.g. AC on advertising, AC on unfair competition, AC on energy, etc.) are in operation. Participants in the markets, representatives of non-commercial associations, and power supervisory authorities are part of these Advisory Councils. This practice allows FAS to evaluate objectively a situation that develops in the relevant markets and increases transparency of decisions made by FAS. ${ }^{29}$

Competition advocacy constitutes all the activities conducted by the competition authorities relating to the promotion of a competitive environment through nonenforcement mechanisms, through their relationships with other governmental entities and by increasing public awareness of the benefits of competition. ${ }^{30}$ Hence,

28 Russia. Report of the Federal Antimonopoly Service on competition policy in 2012 (Jan. 2013).

29 Общественные и консультативные советы [Obshhestvennye i konsul'tativnye sovety [Public and Consultative Councils]] <http://www.fas.gov.ru/community-councils/> (accessed Mar. 12, 2014).

30 See: P.S. Mehta, Competition Culture Key to Successful Competition Regime. Materials of the 3rd BRICS International Competition Conference (Nov. 20-22, 2013, New Delhi). 
the idea of cooperation is realized within the framework of multilateral cooperation in competition matters that takes place by international organizations aimed at promoting cooperation between competition authorities and harmonization of existing competition frameworks (e.g. the International Competition Network (ICN), the Organization for Economic Cooperation and Development, etc.), because competition authorities, likewise states, everywhere encounter similar challenges.

Thus, for instance, within the framework of the ICN Merger Working Group, competition advocacy aims at the promotion of the adoption of best practices in the design and operation of merger review regimes in order to: (i) enhance the effectiveness of each jurisdiction's merger review mechanisms; (ii) facilitate procedural and substantive convergence; and (iii) reduce the public and private time and cost of multi-jurisdictional merger reviews. ${ }^{31}$ In general, the ICN was born out of the recognition by many jurisdictions that multilateral efforts are necessary to ensure convergence and coordination within and between the growing numbers of competition enforcement systems around the world. ${ }^{32}$

Then, cooperation comes down to the regional level. And here we can see both bilateral and multilateral cooperation.

For example, the head of FAS of Russia, Mr. Igor Artemyev, speaking on 21 November 2013 at the 3rd BRICS International Competition Conference in New Delhi, India, talked about the main objectives of the Antimonopoly Authority of the Russian Federation, including liberalization of control of economic concentration which will allow FAS to lower significantly the administrative load on businesses. ${ }^{33}$

The Competition Commission of India, in its turn, fully supported close cooperation between the BRICS competition authorities to forge better relationships among these agencies and help stakeholders, particularly business enterprises, gain confidence in dealings with competition authorities in member countries. The CCl participated in the two BRICS International Competition Conferences held in September 2009, in Russia, and in September 2011, in China. The CCI was a signatory to the joint communiqués signed between the heads of the competition authorities of BRICS countries during these conferences. The $\mathrm{CCl}$ hosted the 3rd BRICS International Competition Conference in New Delhi in 2013 and worked closely with other BRICS countries as coorganizers. The CCl's work with foreign competition agencies will continue to remain a high priority for the agency. ${ }^{34}$

31 Mission of the Merger Working Group (MWG), <http://www.internationalcompetitionnetwork.org/ working-groups/current/merger.aspx> (accessed Mar. 12, 2014).

See: List of the 6th International Competition Network Conference documents (Oct. 10, 2008)

32 F.S. Ugarte, The Int'I Competition Network: Achievements So Far, 22(10) Int'I Fin. L. Rev 1-5 (2003).

333 rd International Conference on competition under the auspices of BRICS, New Delhi (Nov. 22, 2013), at <http://www.fas.gov.ru/fas-news/fas-news_34993.html> (accessed May 31, 2016).

34 Regazzini Emch (note 9 above) at 108. 
As an important part of the pragmatic cooperation of the BRICS Leaders Meeting, we can mention the fact that the heads of the competition authorities of Brazil, Russia, India, China and South Africa jointly held the 2nd BRICS International Competition Conference on 21-22 September 2011 in Beijing, China. These competition authority leaders reaffirmed their readiness in the spirit of openness, development, and cooperation to reach broad consensus among national and regional competition authorities and adopt effective competition policy, to maintain fair competition, protect the interests of consumers, enhance consumers' welfare, and promote the sound development of market economy. ${ }^{35}$

Therefore, we consider that only increased cross-border cooperation through bilateral and multilateral agreements between domestic competition authorities in the developed world can regulate anticompetitive market activities effectively.

\section{Conclusions}

The comparison of legislative provisions of laws on competition and monopolies of BRICS countries shows that they vary in external form and in the various legal techniques used by legislators and created as a result of national specifics of the legal systems and methods of both legal and paralegal regulation of social relations. BRICS countries do have several similarities in their trade practices and competition challenges in their domestic jurisdictions that make it easier to unify methods of global and regional governance.

The analysis of substantial contents of laws on competition and monopolies of the BRICS countries permits us to state that both legal provisions and case law of the BRICS countries under study adhere to the concept of 'market power' that allows us to qualify a number of market actions of enterprises as anticompetitive abuses of their dominant market position irrespective of the market share that they have.

At the same time that there are conventional, generally acknowledged (unified) provisions and norms (e.g. operations on the concept of 'market power' that make it possible to qualify a number of market actions of enterprises as anticompetitive abuses) there are also differences. Thus, for instance, a criterion of 'excessiveness' of concentration and a qualifying sign of its legitimacy serve in BRICS countries different economically significant values (indexes) of reorganized enterprises, for example, a market share in the relevant market (e.g. Russia, China) and the aggregate or individual balance cost of assets (India, South Africa). Likewise, the market share fixed, for example, by Russia, China, and South Africa as a reference point creating a certain framework (limits), which being overstepped attracts the special attention

35 The Beijing Consensus of the 2nd BRICS International Competition Conference between Competition Authorities of Brazil, Russia, India, China and South Africa (Sep. 21, 2011, Beijing, China) (Apr. 19, 2012).

See in detail: Regazzini Emch (note 9 above) at 315-327. 
of antimonopoly authorities, differs. So there is still room for approximation and convergence of approaches.

The expediency of such an approach is of no doubt, as such is indeed the case that the existence of the market power, instead of a market share, is of a critical importance when answering the question of an opportunity for one or another enterprise to influence the competition. At the same time, the market share as a reference point cannot also be recognized as absolutely useless.

It is worth repeating that legislation of the BRICS countries under study reacts identically on the concentration of capital by means of mergers \& acquisitions. And the purpose of the practiced state control consists, naturally, not so much in forbidding operations on concentration as, on the contrary, in stimulating mergers, associations of the national enterprises for strengthening of their competitiveness in the world market. The main objective of a system of such a control is to prevent 'excessive' concentrations if the negative consequences in the economic and social spheres surpass the positive effects.

Control thus extends only to those operations of enterprises, formed by means of merger, acquisition, etc., that surpass the limits set by the antitrust law - by the size or a share in the national market. And for all that, the term 'concentration' can belong to a wide range of operations in the market resulting in a concentration of control, capital, and management of economic activities, regardless of the concrete legal form that it takes. Thus, for example, the multinational corporations mentioned above can be one such mechanism.

The way in which the ideas on increased cross-border cooperation (through both bilateral and multilateral agreements between domestic competition authorities of BRICS countries) come true will be revealed only in the future. At present, we consider, and it has been shown in this article, that the ideas of domestic competition authorities determine the main content of the competition policies that are reflected and consolidated in domestic legal acts and other national documents.

\section{References}

Belikova K. La protección jurídica de la competencia en MERCOSUR, 26 BLC 59-73 (2010).

Figari H., Gomez H., Zuniga M. Hacia una metodología para la definición del Mercado relevante y la determinación de la existencia de posición del dominio, 2 RCPI (2005).

John L. Engaging BRICS. Challenges and Opportunities for Civil Society, 12 OIWPS (2012).

O'Neil J., Stupnytska A. The Long-Term Outlook for the BRICs and N-11 Post Crisis, 192 Goldman Sachs Global Econ. Paper (2009).

Ugarte F.S., The Int'l Competition Network: Achievements So Far, 22(10) Int'l Fin. L. $\operatorname{Rev}(2003)$. 
Whish R., Sufrin B. Competition Law (2d ed. Butterworths, London 1993).

Yang B. Chinese competition policy, 22 BLC (2006).

Беликова К.М. Злоупотребление доминирующим положением в законодательстве, доктрине и правоприменительной практике Европейского Союза и стран Южноамериканского общего рынка - Аргентины, Бразилии и Перу, 7(79) Право и политика (2006) [Belikova K.M. Zloupotreblenie dominirujushhim polozheniem v zakonodatel'stve, doktrine i pravoprimenitel'noj praktike Evropejskogo Sojuza i stran Juzhnoamerikanskogo obshhego rynka - Argentiny, Brazilii i Peru, 7(79) Pravo i politika (2006) [Belikova K.M. Abuse of a dominant position in the legislation, doctrine and practice of the European Union and the countries of the southern common market - Argentina, Brazil and Peru, 7(79) Law and politics (2006)]].

\section{Information about the author}

Ksenia Belikova (Moscow, Russia) - Professor, Department of Civil and Labor Law, Peoples' Friendship University of Russia (RUDN University) (6, Miklukho-Maklaya str., 117198, Moscow, Russia; e-mail: BelikovaKsenia@yandex.ru). 